\title{
Antiinflammatory Effects of Tetracycline- loaded Biodegradable Membranes in Experimental Periodontitis of Beagle Dogs
}

Hyung- Sik Jun'1. Yang- Jo Seol1. Yoon- Jeong Park2. Yong- Moo Lee ${ }^{1}$. Young

In- Cheul Rhyu1. Seung- Jin Lee ${ }^{2}$. Soo- Boo Han ${ }^{1}$. Sang- Mook Choi ${ }^{1}$ Soo- Kyoung Kwon ${ }^{3}$ and Chong- Pyoung Chung ${ }^{1}$

${ }^{1}$ Dept. of Periodontology, College of Dentistry, Seoul National Unive rsity,

I. Introduction

The ultimate objective of periodontal therapy is the regeneration of the periodontium destroyed by inflammatory periodontal disease. This means the formation of new connective tissue attachment with connective tissue fibers inserting into diseased root surface with formation of new cementum and bone regeneration. Guided tissue regeneration( GT R) provides environment for regeneration of cementum, periodontal ligament, and bone by placing a barrier membrane between the gingiva and the diseased root surface ${ }^{1-3)}$. T he purpose of the barrier membrane is not only to prevent proliferation of gingival epithelium and connective tissue into the dentogingival wound space, but also to divert mechanical stress from the coagulum- tooth interface, and thus allow undisturbed organization of the blood clot and promote early attachment of connective tissue elements to the root surface ${ }^{4)}$.
Post- operative contamination of the membrane or infection of the surgical site is a problem often encountered5) using barrier membrane for GT R therapy. This is especially true when the membrane is exposed ${ }^{6}$. Clinically, many techniques have been tried to prevent the exposure of the membrane. But the exposure of the membrane due to the morphology of the tooth itself ${ }^{7)}$, incomplete coverage of the membrane by the gingival flap ${ }^{8)}$, dehiscence of the gingival flap9), or gingival recession ${ }^{10}$ ) is a common complication resulting from guided tissue regeneration therapy. This increases incidence of infection of the newly formed tissue beneath the exposed membrane when it is exposed ${ }^{11)}$. Microorganisms can adhere to and colonize exposed membranes leading to the development of a nidus of infection. Microbial adherence has been associated with infection and subsequent rejection of many biomaterials ${ }^{12)}$. Increased bacterial contamination of the site where a membrane was

*T his study was supported by the Korea Science \& Engineering foundation( Grant no. 97- 0403- 0701- 3). 
used could be seen ${ }^{6}$. Some have reported that e- PT FE membranes show higher incidence of bacterial infection ${ }^{4,13-15)}$. Infections of the membranes affect clinical outcomes. Many studies have show $n$ that contamination of the membranes and the degree of infection are related to decreased clinical attachment gain ${ }^{10,16-18)}$. It has been reported that clinical healing response is related to whether the membrane is infected or not ${ }^{19)}$. T his explains the importance of infection control as a part of regenerative attempt ${ }^{20)}$.

In many researches, sy stemic antibiotics has been administrated to prevent postoperative infection after guided tissue regeneration therapy ${ }^{21-26)}$. T etracy cline is effective on a wide range of periodontal pathogens $^{27-32)}$, and inhibits connective tissue destruction by inhibiting neutrophil collagenases ${ }^{33)}$. Due to these effects, tetracycline has been used sy stemically or locally for treatment of periodontal diseases ${ }^{34)}$. T etracy cline binds to the root surface and is slowly released from the root surface ${ }^{35)}$. Reattachment or regeneration of the periodontal tissues may also be enhanced by promotion of fibroblast attachment, conditioning of root surfaces, and inhibition of collagenase activity ${ }^{\left.36-{ }^{38}\right)}$. A Iso tetracy cline can increase attachment ${ }^{39}$ ), inhibit bone resortption in vitr $0^{37,40)}$, and increase collagen formation of osteoblasts ${ }^{41}$. Pretreatment of dentin with tetracy cline increased migration of periodontal ligament cells. A Iso fibronectin adhered better to the root surface when the root was treated with tetracy cline ${ }^{42)}$.

In this study, membrane was formed by polyglicolide mesh coated on $10 \%$ tetracy- cline( T C) containing poly lactic acid. The purpose of this study is to evaluate antiinflammatory and antimicrobial effects of T cloaded biodegradable membrane in experimentally induced periodontitis in beagle dogs and to investigate release characteristics of the T c- loaded membrane.

\section{Materials and Methods}

\section{Formation of the Tetracycline- loaded Membrane}

T he membrane used in this experiment was formed as below ${ }^{43)}$. PGA meshes were knitted with a tube knitter (Koike Ltd., Nara, Japan) with PGA (poly gly colic acid, viscosity 18,000 poise, Samy ang Co., Seoul, Korea). Initial strength of the mesh was $5.2 \mathrm{~g} / \mathrm{d}$. T he mesh was spread out, fixed and covered with poly lactic acid( MW 300,000, Purac Biochem BV, Gorinchem, Holland). T his was dried for 24 hours at room temperature and the was evaporated. T his was vacuum dried for 24 hours and the remaining solvent was removed. T o produce a membrane containing tetracy cline, first, poly lactic acid was dissolved in methy lene chloride and ethylacetate was added. T etracy cline( Sigma Chemical Co., St Louis, MO, USA ) was mixed with dissolved polylactic acid at $10 \%$ weight ratio. PLA solutions were cast on PGA meshes by using a doctoring blade and solvents were evaporated in air for 24 hours and further dried under vacuum for 24 hours to remove residual solvents. Membranes used in the experiment was sterilized with $\mathrm{EO}$ gas one day before the experiment. 


\section{Experimental Animals}

Healthy beagle dogs weighing approximately $15 \mathrm{Kg}$ were used regardless of sex. Of the six, five beagle dogs were used to evaluate the efficacy of the membrane containing tetracy cline on guided tissue regeneration. Three dogs were assigned to the test group which was implanted with tetracycline- loaded membrane( Group I). T wo dogs were assigned to the membrane without tetracy cline (Group II) and no membrane used(Group III) contralaterally. T o prevent the influence of tetracy cline, tetracycline- loaded membranes were used in the test group only. One remaining dog was used to evaluate the concentration of tetracy cline released into the gingival sulcus.

\section{Defect Formation}

Bony defects were formed 2- 3 months before membrane placement. General anesthesia was induced in experimental animals by infiltration of equal parts of $2 \%$ Xylizine hy drochlroride(Rumpun , Bay er Korea, Korea) and ketamine hy drochlroride (Ketalar, Yuhan, Korea). Local anesthesia was obtained by infiltration of $2 \%$ lidocaine containing 1:100,000 epinephrine for bleeding control. Upper canine and 2nd premolar, or lower 3rd and 4th premolars were used in the experiment. Full thickness flap was raised after sulcular incision was extended one tooth mesial and distal to the test tooth. Vertical incision was added when necessary. Alveolar bone defects were formed with low speed carbide round bur and chisel after removal of all granulation tissues and calculus. Class II furcation defects were formed in premolars according to following dimensions; $5 \mathrm{~mm}$ vertically from CEJ, mesiodistally to the line angle, buccolingually 2- $3 \mathrm{~mm}$ deep. In canines, dehiscence defect measuring $4 \mathrm{~mm}$ wide and $5 \mathrm{~mm}$ deep from neighboring alveolar crest was formed. T o prevent natural healing and to induce chronic inflammation, alveolar bone defect was filled with silicone rubber impression material (EXAMIXT M, GC A merica Inc., Japan) and sutured with black silk. Penicillin G procaine(Pfizer Co., New York, U.S. A.) was injected for 5 day s intramuscularly and soft fluid diet was given for 2 weeks. Stitch out was done 2 weeks after operation.

\section{Surg ic al Proc edure}

2- 3 months after defect formation, general anesthesia was induced according to the same procedure as described previously. Full thickness flap was raised including one tooth mesial and distal to the test area with sulcular incision. Scaling and root planing was done after removal of rubber impression materials. T o prevent crossover effect, only tetracy cline- loaded membranes were used in the test group. The membrane was trimmed to cover the defect 2- 3mm over the bone. The membrane was sling sutured on the tooth and flap was repositioned. Complete coverage of the membrane was attempted. Penicillin G procaine(Pfizer Co., New York, USA) was injected intramuscularly for 7 days and soft fluid diet was given for 2 weeks. Oral 
hygiene was maintained with $0.1 \%$ chlorhexidine three times a week from post- op 2 weeks. Stitch out was done post- op 2 weeks.

In two weeks postsurgery, the dogs were sacrificed. Maxilla and mandibles were block- resected and fixed in $10 \%$ formalin for histologic preparation and analy sis. Undecalcified specimens were prepared according to Donath and Breuner' $s$ method $^{44)}$.

5. Me a surements of Clinic al Parameters and Mic robiolog ic al Assay

Following clinical parameters were measured directly before surgery, and 1, 2, 4 weeks post- operatively. GI( Gingival Index, Loe \& Silness 1963) ${ }^{45)}$, PI(Plaque Index, Silness \& Loe 1964) ${ }^{46)}$ of the test site were measured. Periopaper strip (Proflow Inc., NY, USA ) was inserted in the gingival sulcus for 30 seconds to sample gingival crevicular fluid and GCF was measured with Periotron 8000 (Proflow Inc., NY, USA).

Microbiological assay was done after measurement of clinical parameters. To sample subgingival plaque three paper points(DiaDent Group International, Chongju, Korea)were inserted in the pocket for 30 seconds and these were placed in Moller's VMGA III and immediately moved to the anaerobic chamber(Forma, $\mathrm{OH}$, USA), and mixed with a vortex mixer(Vortex mixer) for 30 seconds. Serial dilution of the VMGA III solution containing bacteria was done to $1 / 10,1 / 100,1 / 10000$ of the original solution. $100 \mu l$ of this solu- tion was spreaded on selective agar plates. A erobic bacteria was plated on $5 \%$ sheep blood agar plate and cultured in a 10\% $\mathrm{CO}^{2}$ chamber at $37{ }^{\circ} \mathrm{C}$ (Vision, Korea), and anaerobic bacteria was plated on T ryptic soy agar plate containing $5 \%$ sheep blood, vitamin $\mathrm{K}$, and hemin and cultured in an anaerobic chamber containing $\mathrm{H}_{2}, 10 \% \mathrm{CO}_{2}$, $80 \% \mathrm{~N}_{2}$ at $37^{\circ} \mathrm{C}$. A fter 7 days, the total number of CFU of aerobic bacteria and anaerobic bacteria was calculated.

\section{Bio assay of Released Tetracycline}

T etracy cline- loaded membranes were placed on left and right upper canines and 2nd premolars, and on lower 2nd and 3rd premolars according to the above procedure. Method of Bennet et al ${ }^{47-49)}$ was modified to investigate the concentration of tetracy cline in the tissues. At post- operatively $1,3,5,7,14$ day s, Periopaper strip ${ }^{\circledR}$ (Proflow Inc., NY, USA) was placed between the gingiva and the membrane for 30 seconds to detect tetracy cline in tissue fluid. These periopapers were placed on a $B$. cereus cultured nutrient agar plate and cultured for $36-48$ hours at $37^{\circ} \mathrm{C}$. A fter culture, inhibitory zones were measured with a caliper placed perpendicular to the periopaper and measured to the nearest $\mathrm{mm}$. Standard curve was calculated by serial dilution of tetracy cline. T he concentrations of the tetracycline released in the gingival sulcus were measured indirectly with standard curve.

\section{Statistic al Ana ly sis}


Table 1. Comparison of GI of the three groups (mean \pm SE)

\begin{tabular}{lllll}
\hline & Baseline & 1 week & 2 weeks & 4 weeks \\
\hline Group I & $1.58 \pm 0.15$ & $1.83 \pm 0.13$ & $1.08 \pm 0.19 *$ & $1.17 \pm 0.21 *$ \\
Group II & $1.25 \pm 0.25$ & $1.75 \pm 0.48$ & $1.50 \pm 0.50$ & $1.50 \pm 0.25$ \\
Group III & $1.75 \pm 0.48$ & $1.50 \pm 0.29$ & $1.75 \pm 0.25$ & $1.50 \pm 0.25$ \\
\hline
\end{tabular}

*: T he mean difference is significant at the 0.05 level from baseline.

Group I : tetracy cline- loaded membrane group

Group II : tetracy cline- unloaded membrane group

Group III : without membrane group

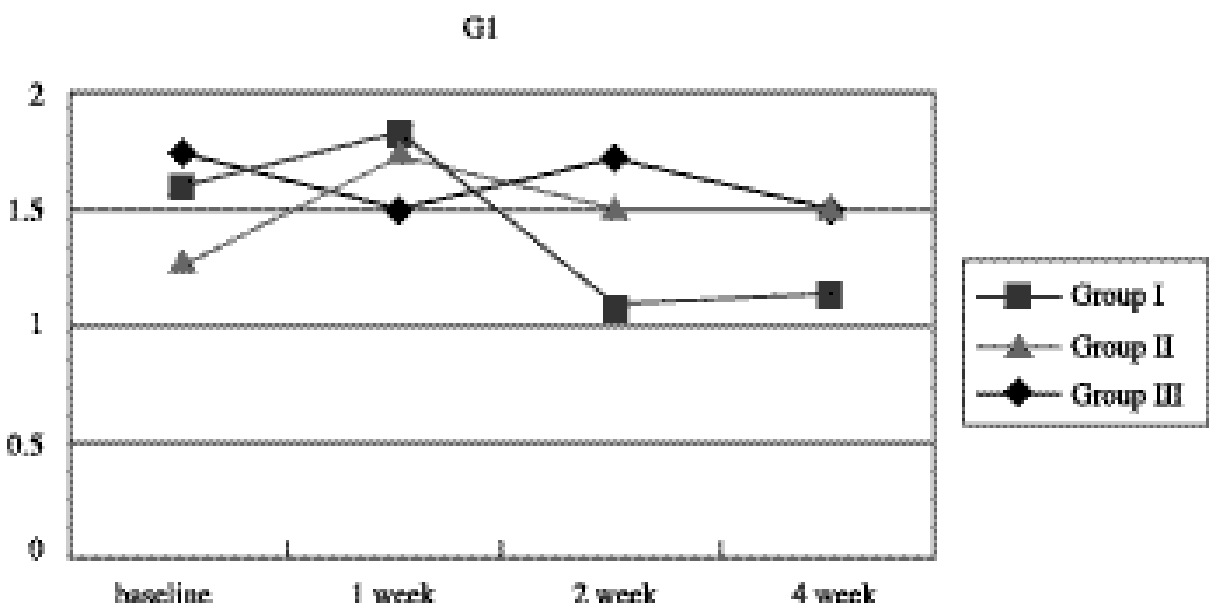

Figure 1. Comparison of GI of the three groups. GI of the Group I at post- op 2 and 4 weeks showed signifiant decrease from baseline. GI of the Group II and the Group III showed slight

Table 2. Comparison of PI of the three groups(mean $\pm \mathrm{SE}$ )

\begin{tabular}{lllll}
\hline & Baseline & 1 week & 2 weeks & 4 weeks \\
\hline Group I & $2.00 \pm 0.15$ & $1.58 \pm 0.13^{*}$ & $1.50 \pm 0.19 *$ & $1.42 \pm 0.21 *$ \\
Group II & $1.50 \pm 0.50$ & $2.00 \pm 0.00$ & $1.75 \pm 0.48$ & $1.75 \pm 0.48$ \\
Group III & $2.00 \pm 0.41$ & $2.00 \pm 0.00$ & $1.50 \pm 0.29 *$ & $1.25 \pm 0.25 *$ \\
\hline
\end{tabular}

* : T he mean difference is significant at the 0.05 level from baseline.

Sample size was calculated on a tooth basis. Homogenicy test of standard deviation was done on each group at each period to assess whether application of parametric analy sis is appropriate. Repeated measures ANOVA method was used to analyze the effect of treatment, and to compare the interactions of treatment method and time. For posthoc multivariate comparison, Dunnett test was done. 0.05 was taken for a error. SPSS software version 7.0 ( SPSS Inc., Chicago, IL. USA) was used for statistical analy sis. 
ri

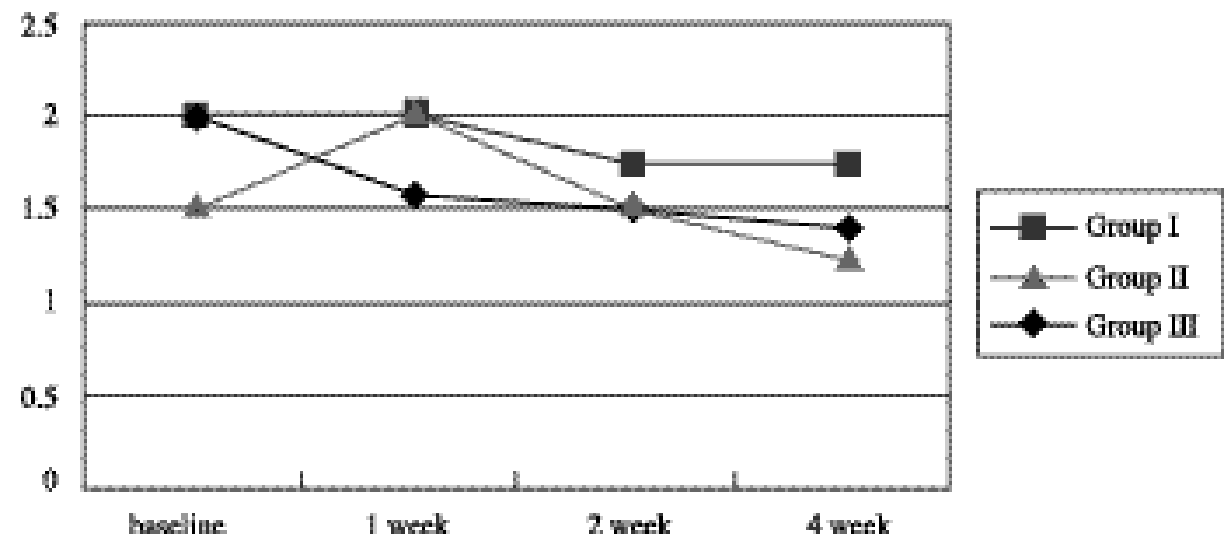

Figure 2. Comparison of PI of the three groups. Plaque index of the Group I and the Group III decreased. In the Group II, Plaque index increased.

Table 3. Comparison of GCF volume of the three groups(mean $\pm \mathrm{SE}$ )

\begin{tabular}{lllll}
\hline & Baseline & 1 week & 2 weeks & 4 weeks \\
\hline Group I & $80.83 \pm 6.60$ & $104.83 \pm 5.85$ & $93.42 \pm 7.05$ & $86.25 \pm 7.30$ \\
Group II & $74.00 \pm 14.39$ & $99.50 \pm 25.47$ & $82.25 \pm 5.81$ & $76.00 \pm 8.42$ \\
Group III & $73.25 \pm 26.16$ & $119.25 \pm 15.43$ & $80.50 \pm 27.73$ & $67.00 \pm 12.25$ \\
\hline
\end{tabular}

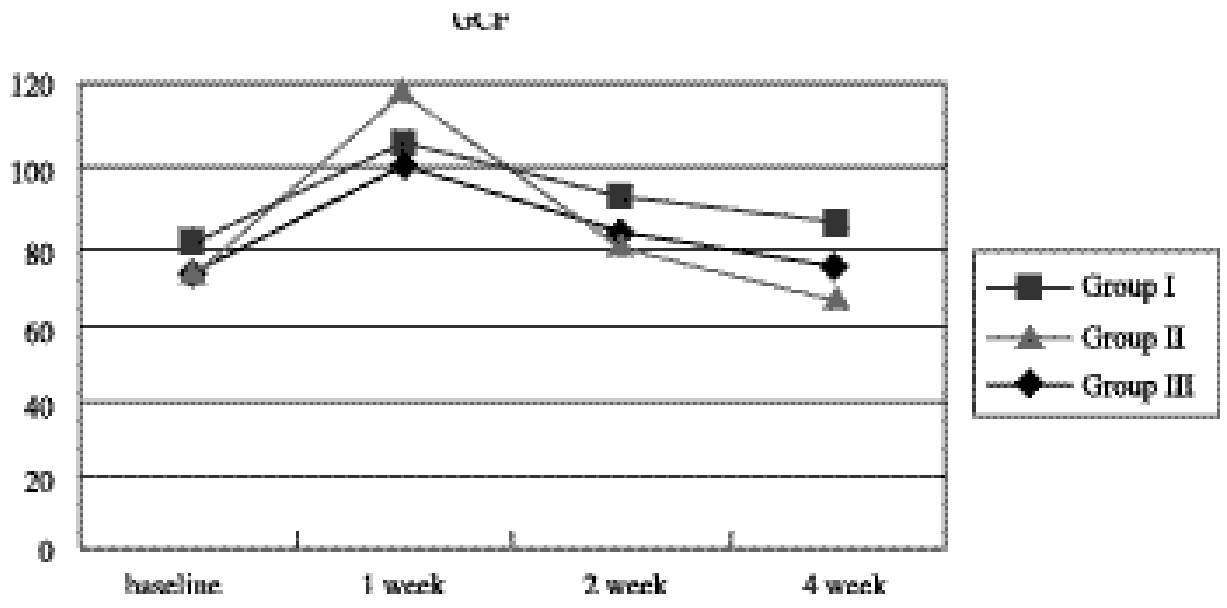

Figure 3. Comparison of GCF volume of the three groups. Post- op 1 week values in all three groups are signific antly increased from baseline. Thereafter GCF volumes decreased with time to a level similar to base line measurements at week 4 .

III. Re sults
1. Ba seline examinations

Difference in dependent variables( GI, PI, 
Table 4. Total CFU of anaerobic bacteria(mean \pm SD)

\begin{tabular}{lllll}
\hline & Baseline & 1 week & 2 weeks & 4 weeks \\
\hline Group I & $6.31 \pm 0.21$ & $4.44 \pm 0.24^{+*}$ & $5.41 \pm 0.27^{*}$ & $5.31 \pm 0.38^{*}$ \\
Group II & $6.29 \pm 0.23$ & $6.21 \pm 0.38$ & $6.04 \pm 0.43^{\$}$ & $5.80 \pm 0.44^{\$}$ \\
Group III & $6.30 \pm 0.31$ & $5.52 \pm 0.45$ & $5.32 \pm 0.37^{*}$ & $5.02 \pm 0.44^{*}$ \\
\hline
\end{tabular}

CFU of anaerobic bacteria was expressed as $\log 10$ of the value.

*: T he mean difference was significant at the 0.001 level from baseline.

+: T he mean difference was significant at the 0.001 level between Group I and group II, III.

$\$:$ T he mean difference was significant at the 0.001 level between Group I, III and group II.

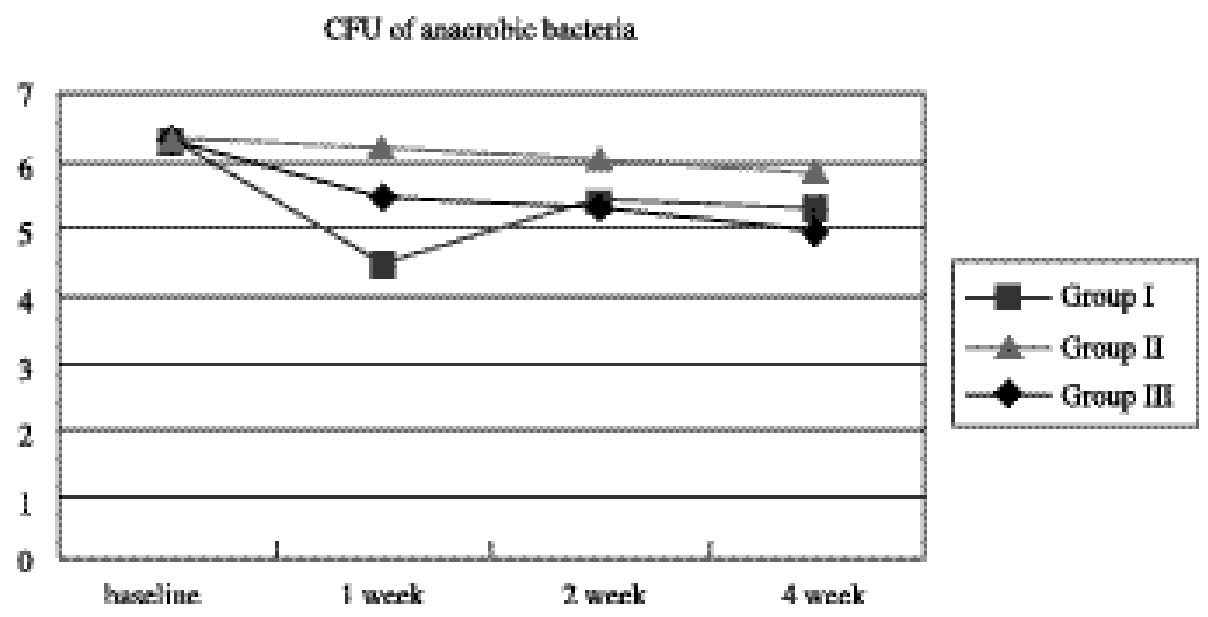

Figure 4. Total C FU of anaerobic bacteria. C FU of bacteria was expressed as log 10 of the value. Total CFU of the Group I was less than that of the Group II throughout the study period.

Table 5. Total CFU of aerobic bacteria (mean \pm SD)

\begin{tabular}{lllll}
\hline & Baseline & 1 week & 2 weeks & 4 weeks \\
\hline Group I & $5.31 \pm 0.27$ & $4.41 \pm 0.20^{+*}$ & $5.20 \pm 0.31$ & $5.26 \pm 0.37$ \\
Group II & $5.37 \pm 0.16$ & $5.51 \pm 0.21$ & $5.40 \pm 0.19$ & $5.32 \pm 0.26$ \\
Group III & $5.39 \pm 0.25$ & $5.35 \pm 0.22$ & $5.25 \pm 0.24$ & $5.43 \pm 0.31$ \\
\hline
\end{tabular}

CFU of anaerobic bacteria was expressed as $\log 10$ of the value.

*: T he mean difference was significant at the 0.001 level from baseline.

$+:$ T he mean difference was significant at the 0.001 level between Group I and group II, III.

GCF , total colony forming units of anaerobic bacteria, total colony forming units of aerobic bacteria) were not statistically significant at baseline among groups.

GI in the membrane group(Group I, II) showed a slight tendency to increase at 1 week after surgery. In the Group I, this decreased significantly 2 weeks after 2. Clinic al mea surements surgery $(p<0.05)$ and this $w$ as maintained 


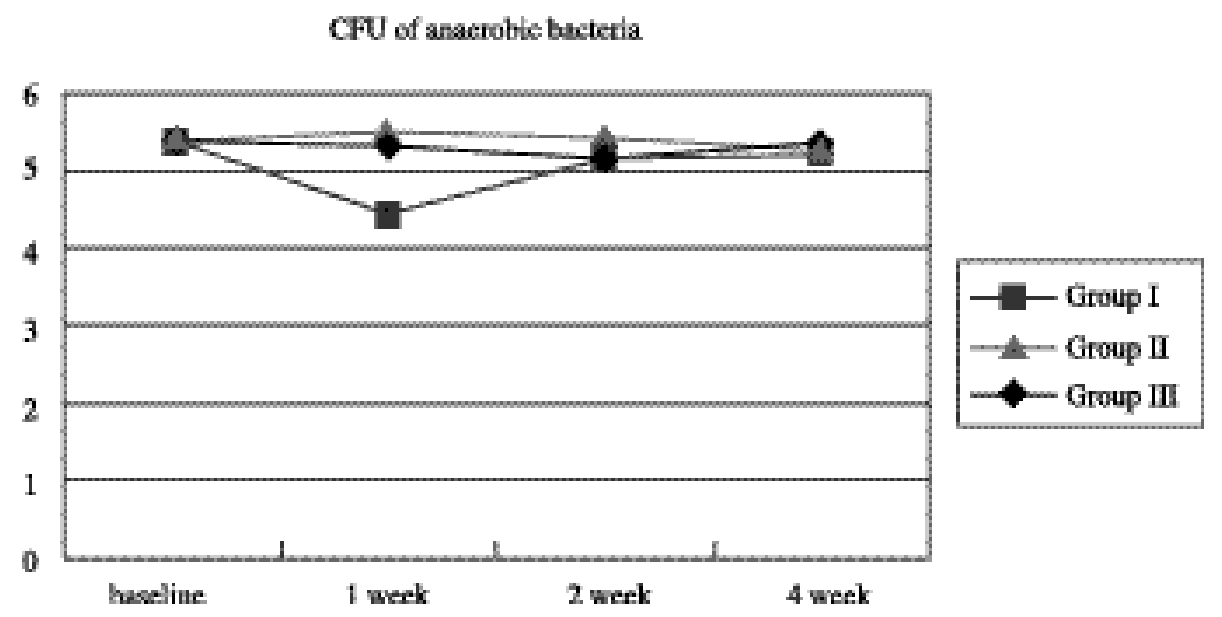

Figure 5. Total CFU of a erobic bacteria. C FU of bacteria was expressed as log 10 of the value.

Table 6. Tetracycline release kinetics

\begin{tabular}{lrrrrr}
\hline days & 1 day & 3 days & 5 days & 7 days & 14 days \\
\hline concentration & 52.50 & 35.00 & 30.83 & 29.17 & - \\
$(\mu \mathrm{g} / \mathrm{m} \ell)$ & \pm 14.40 & \pm 13.42 & \pm 14.63 & \pm 13.20 & \\
\hline
\end{tabular}

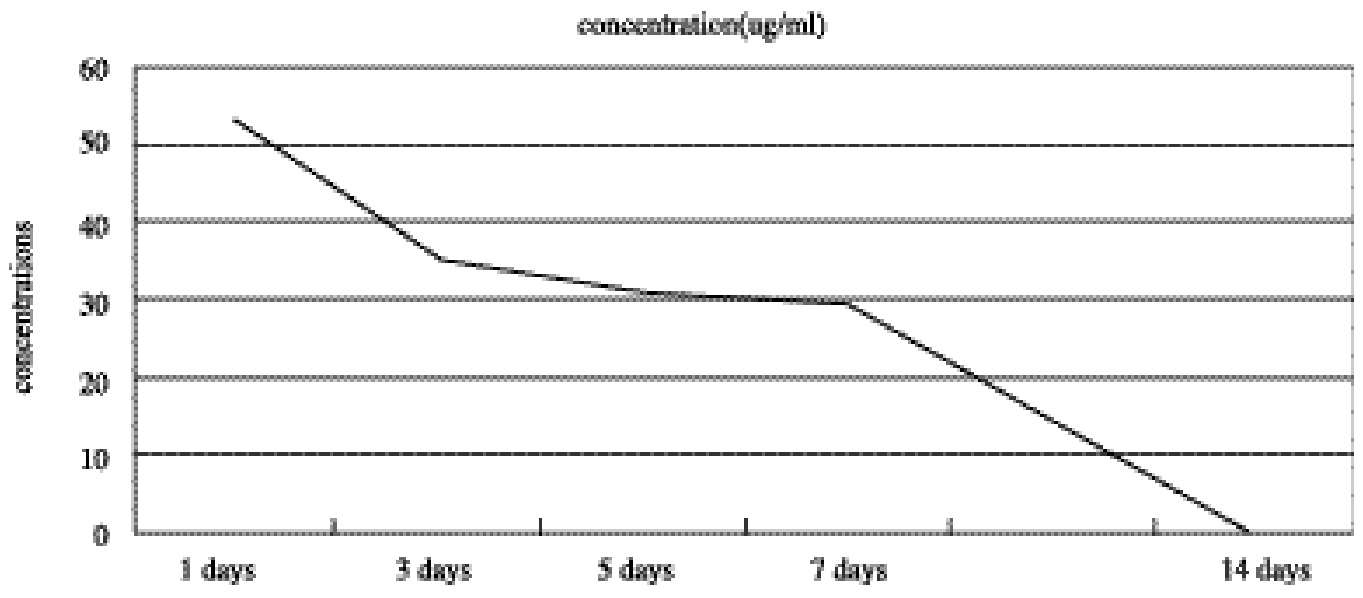

Figure 6. Tetracycline release kinetics. At day 1 Tc was released at $52.50 \pm 14.40 \mu \mathrm{g} / \mathrm{m} \ell$. Tc was ste adily released at day $3,5,7$ at $35.00 \pm 13.42 \mu \mathrm{g} / \mathrm{ml}, 30.83 \pm 14.63 \mu \mathrm{g} / \mathrm{ml}, 29.17 \pm 13.20 \mu \mathrm{g} / \mathrm{ml}$ each. On the 14th day, no Tc was detected.

till the 4th week. GI of the T c- unloaded group(Group II) or of the control group(Group III) was slightly higher than that of the Group I throughout the study. But no statistical difference was seen between the groups(T able 1, Figure 1). Plaque index of the Group I and Group III decreased with time. But in the T cunloaded membrane group, plaque index increased. In Group I, the PI scores at 4th 
week was significantly less than that at the baseline $(p<0.05)$, in Group II, this was higher at 1st week and maintained at this level at 2, 4 weeks but these scores were slightly higher than that of the Group I or than that of the Group III. In Group III, PI at 1st week did not differ from the baseline but showed a tendency to be decrease at 2 and 4 weeks( T able 2, Figure 2). T he volume of gingival crevicular fluid measured with Periotron ${ }^{\circledR}$ was similar in all the groups. The volume measured at the first week was higher than that of the baseline but this decreased and at the 4th week, the measured volume was similar to that of the baseline( $\mathrm{T}$ able 3 , Figure 3 ) .

\section{Mic robiolog ic al Assay}

T otal anaerobic and aerobic colony forming units of each group is shown in tables 4, 5 and figures 4, 5. CFU s of anaerobic and aerobic bacteria were expressed as log 10 of the value.

\section{(1) Anaerobic Bacteria}

In the Group I, post- operative number of total colony forming units was decreased at 1 week and rebounded at 2, 4w eeks slightly. In the group II and III, CFU were slowly decreased throughtout the study ( $\mathrm{T}$ able 4 , Figure 4). In the view of time point, there was significant differences group I and group II, III at 1 week. A Iso, there were significant differences between group II and group I, III at 2, 4 weeks $(p<0.001)$.

(2) Aerobic Bacteria

In the group I, as the pattern of cfu of anaerobic bacteria post- operative number of total colony forming units was decreased at 1 week but rebounded nearly baseline level at 2, 4weeks. In the group II and III, CFU were slowly decreased throughtout the study ( $T$ able 5, Figure 5). In the view of time point, there was significant differences group I and group II, III at 1week. But, there were no significant differences among any groups at 2, 4 weeks.

\section{Tetracycline Release Kinetic s}

T o test the release kinetics of loaded tetracy cline from the membrane, the diameter of the inhibition zone formed in the nutrient agar plate was measured and the concentrations of released tetracy cline were calculated from the standard curve prepared. T his was measured at a total of 6 sites and the average concentration was calculated. On the first day, the measured concentration was $52.50 \pm 14.40 \mu \mathrm{g} / \mathrm{ml}$ which is quite high and on the $3 \mathrm{rd}, 5$ th and the 7 th day, this was released consistently at 35.00 $\pm 13.42 \mu \mathrm{g} / \mathrm{ml}, 30.83 \pm 14.63 \mu \mathrm{g} / \mathrm{ml}, 29.17 \pm$ $13.20 \mu \mathrm{g} / \mathrm{ml}$ each ( T able 6. Figure 6). But on the 14th day, T c was not detected.

\section{Disc ussion}

T his study was done to evaluate whether T c- loaded membranes can inhibit contamination and bacterial colonization of the membrane, and infection of the surgical site in initial healing period. T etracy cline, a wide- spectrum antibiotic was loaded in a biodegradable membrane and the following was investigated 1) Whether T c- loaded membrane could decrease clinical signs of 
inflammation and the number of bacteria found in a experimental periodontitis site in a beagle dog 2) the release kinetics of T etracy cline.

Membranes used in this study were not seen to be cytotoxic in a previous study using the poly mer used in this membrane ${ }^{43)}$. This membrane started to be degraded 4- 6 weeks after placement in the subgingival tissue of rat without any adverse tissue reaction ${ }^{50)}$.

T he decrease in clinical gingival inflammation and plaque accumulation in the $\mathrm{T} \mathrm{C}$ loaded membrane group was greater than that of the T c- unloaded membrane group, but this difference was not statistically significant. In the T c- loaded membrane group, GI and PI tended to be decreased from post- op week 1 to week 4. But, GCF volume measured by Periotron ${ }^{\circledR}$ increased at 1 week after surgery in all three groups and decreased to same level as baseline and was similar between all three groups throughout the test period. The total colony forming units(CFU) of anaerobic bacteria in the T c- loaded membrane group was less than that of the Tc- unloaded membrane group at all time points. T hough rebounded at 2 week, the cfus of both anaerobe and aerobe of T c- loaded membrane group were significantly decreased at 1 week compared to not only baseline but also the other groups. T his antibacterial effect may be helpful initial healing of the tissue regenerative process.

In this study, the concentrations of tetracycline released from the membrane was indirectly measured by sampling TC released in the gingival sulcus with peri- opaper ${ }^{47-49)}$. The level of T c released from the membrane was the highest at day 1 at $52.50 \pm 14.40 \mu \mathrm{g} / \mathrm{ml}$, and on day $3,5,7$, was steadily released at the concentrations of $35.00 \pm 13.42 \mu \mathrm{g} / \mathrm{ml}, 30.83 \pm 14.63 \mu \mathrm{g} / \mathrm{ml}$, $29.17 \pm 13.20 \mu \mathrm{g} / \mathrm{m} \ell$. But, T c was not observed at day 14 . Kim et al51 have reported in an in vivo study that $\mathrm{T} \mathrm{c}$ was released from a $10 \%$ T c- loaded membrane at the concentration of $52 \mu \mathrm{g} / \mathrm{ml}$ at day 1 and $w$ as steadily released thereafter for 4 weeks. But in that study, the release kinetics of the Tc was seen by removal of $T c$ at various time points after placement of the membrane in the subcutaneous tissue in the rat. Markman et al tested a cellulose membrane containing $T c$ to investigate its release kinetics but this experiment was also under closed conditions. In that experiment, slow release of $\mathrm{T} c \mathrm{w}$ as seen at concentration of $218 \mu \mathrm{g} / \mathrm{ml}$ at day 1 and this release was continued till day 12 at $20.8 \mu \mathrm{g} /$ m ${ }^{52)}$. In this experiment, T c- loaded membrane was placed in periodontitis- alveolar bone defect and gingivitis- induced site in beagle dog, and released $\mathrm{T} c$ in the sulcus was measured. Most microorganisms found in the gingival sulcus were susceptible to 8 $\mu \mathrm{g} / \mathrm{ml}$ of $\mathrm{T} \mathrm{c}^{27}$. Though T c was not detected in the sulcus at day 14 , it was slowly released to the sulcus at levels above MIC till day 7 .

Relatively many GTR barriers are exposed to the oral environment. Some studies have reported that in $70 \%$ of GT R cases, membranes were exposed and bacteria found on the surface of the exposed membranes ${ }^{10,19)}$. Infection of the surgical site and the membrane can occur between 
the gingival flap and the tooth surface. A Iso when the membrane is exposed, bacterial infection of the membrane is enhanced and as the apical migration of the epithelium occurs, a pocket- like structure is formed external to the membrane. Bacterial colonies have been observed with light microscopes on both the external and the internal surface of the membrane ${ }^{4)}$. Mombelli et al has reported that putative periodontal pathogens were cultured from retrieved GT R barriers. Gram- negative, anaerobic rods made up $31 \%$ of the total organisms from all samples ${ }^{53)}$. It is not clear to what extent bacterial colonization of GT R materials compromise success of therapy, but it can be safely assumed that microbial colonization causes complications. Some have reported that attachment of bacteria on the removed barrier membranes are related to limited clinical attachment gain $^{10,16,54,55)}$.

Sy stemic antibiotics have been used after GT R therapy to decrease the incidence of infection of the surgical site or membrane. Demolon et al reported that when microbiological assay with DNA probes were done on bacteria sampled with paper points, total number of bacteria increased when time passed regardless of use of post- operative sy stemic antibiotics ${ }^{21)}$. It was concluded that when a membrane is placed, the number of bacteria is increased as time passes whether sy stemic antibiotics are used or not $^{21,56)}$. Local application of chlorhexidine is necessary to inhibit infection of the membrane or surgical site, but this is limited to post- operative 1st week when it is difficult for the patient to maintain oral hy giene. In this study, almost no oral hy giene measures were performed for 2 weeks after surgery. A fter this period, limited oral hy giene measures were taken 2- 3 times a week with chlorhexidine. T his differs from usual human studies. When membranes are placed in human subjects, postoperative chlorhexidine gargling is prescribed and professional oral prophylax is is done to inhibit contamination of the membrane or infection of the surgical site. As mentioned previously, the results of this study show that though $\mathrm{T}$ c- loaded membrane is more effective than T c- nonloaded membrane, as membranes tend to be infected by bacteria, the number of colony forming units found in the T c- loaded membrane group, was greater than that found in the control group. Meticulous plaque control during surgery and postoperatively or the use of wide- spectrum antibiotics cannot completely inhibit bacterial contamination of the membrane or infection of the surgical site. A septic technique is necessary to offer better conditions for regenerative therapy. Local application of antibiotics directly on the membrane may be more effective ${ }^{57)}$.

In this study, to prevent crossover effect of $\mathrm{T} c$, split mouth design was not used. Because, it is possible for $T c$ released from one site in the oral cavity to influence other sites. It has been show $n$ that following placement of tetracycline fibers, the drug is transiently detected in the serum or sali$v a^{58)}$, which may effect the microbiological response. T c was show $n$ to be slowly released at concentrations higher than MIC and inhibit gingival inflammation and growth 
of bacteria in the oral cavity. Thus, the use of T c- loaded membranes can result in improved clinical outcome from adjunctive antiinflammatory and antimicrobial effect of tetracy cline on guided tissue regeneration using barrier membrane.

\section{Ac knowledgment}

T he authors wish to thank Mr. Lee SC, Miss Kim KH, and Dr. Ko YK for their help in technical assistance and preparing this manuscript.

\section{References}

1. Karring $\mathrm{T}$, Nyman S, Gottlow J, Laurell L. Development of the biological concept of guided tissue regeneration animal and human studies. Periodontol 2000 1993;1:26- 35

2. Greenstein G, Caton JG. Biodegradable barriers and guided tissue regeneration. Periodontol 2000 1993;1:36- 45

3. Gottlow J. Guided tissue regeneration using bioresorbable and nonresorbable devices: Initial healing and long- term results. J Periodontol 1993;64:1157- 1165

4. Selvig KA, Nilveus RE, Fitzmorris $L$, Kersten $B G$, Khorsandi SS. Scanning electron microscopic observations of cell populations and bacterial contamination of membranes used for guided tissue regeneration in humans. J Periodontol 1990;61:515- 520

5. Dankert J, Hogt A H, Feijon J. Biomaterial polymers: Bacterial adhesion, colonization and infection. Crit Rev
Biocom 1986;3:219- 301

6. Passariello C, T haller MC, Selan L. Periodontal regeneration procedures may in duce colonization by gly coraly $x$ producing bacteria. Med Micro Immunol 1991;180:67- 72

7. Lu HK. topographical characteristics of the root trunk length related to guided tissue regeneration. J Periodontol 1992;63:215- 219

8. Warrer K, Karring T . Guided tissue regeneration combined with osseous grafting in suprabony periodontal lesions. An experimental study in the dog. J Clin Periodontol 1992;19:373380

9. Rominger JW, T riplett RG. The use of guided tissue regeneration to improve implant osseointegration. J Oral Maxillofac Surg 1994;52:106- 112

10. Selvig $K A$, Kersten $B$, Chamberiain ADH, Wikesj_ UME, Nilve? RE. Regenerative surgery of intrabony periodontal defects using ePT FE membranes. Scanning electron microscopic evaluation of retrieved membranes versus clinical healing. J periodontol 1992;63:974- 978

11. Chen YT, Wang HL, Lopatin DE, O' Neal R, MacNeil L. Bacterial adherence to guided tissue regeneration barrier membranes exposed to the oral environment. J Periodontol 1997;68:172179

12. Gristina $A G, O$ ga $M, W$ ebb $L X$, Hobgood CD. A dherent bacterial colonization in the pathogenesis of osteomy elitis. Science 1985;228:990993 
13. Grevstad JH, Leknes KN. UItrastructure of plaque associated with poly tetrafluoroethy lene membranes used for guided tissue regeneration. J Clin Periodontol 1993;20:193- 198

14. Tempro PJ, nalbandian J. Colonization of retrieved poly tetra- fluoroethy lene membranes: Morphological and microbiological observations. J Periodontol 1993;64:162- 168

15. Simion $M$, T risi $P$, Maglione $M$, Piattelli A. A preliminary report on a method for studying the permeability of ePT FE membranes to bacteria in vitro. A scannong electron microscopic and histologic study. J Periodontol 1994;65:755- 761

16. Nowzari H, slots J. Microorganisms in poly tetrafluoroethy lene barrier membranes for guided tissue regeneration. J Clin Periodontol 1994;21:203- 210

17. Simion M, Baldoni M, Rossi P, Zaffe D. A comparative study of the effectiveness of ePTFE membranes with and without early exposure during the healing period. Int J Periodontics Restorative Dent 1994;14:167- 180

18. Nowzari H, Matian F, Slots J. Periodontal pathogens on poly tetrafluoroethy lene membrane for guided tissue regeneration inhibit healing. J Clin Periodontol 1995;22:469- 474

19. Guillemin MR, Mellonig JT, Brunsvold MA, Healing of periodontal defects treated by decalcified freezedried bone allografts in combination with ePT FE membranes. I. Clinical and scaaning electron microscopic analy sis. J Clin Periodontol 1993;20:528- 536
20. New man MG. T he role of infection and anti- infection treatment in regenerative therapy. J Periodontol 1993;64:1166- 1170

21. Demolon IA, Persson GR, Moncla BJ, Johnson RH, A mmons WF. Effects of antibiotic treatment on clinical conditions and bacterial grow th with guided tissue regeneration. J Periodontol 1993;64:609- 616

22. Becker W, Becker BE, Berg L, Prichard J, Caffesse R, Rosenberg E. New attachment after treatment with root isolation procedures: Report for treatment Class III and Class II furcations and vertical osseous defects. Int J Periodontics Restorative Dent 1988;8(3):9- 23

23. Schallhonn RG, McClain PK. Combined osseous composite grafting, root conditioning, and guided tissue regeneration. Int $J$ Periodontics Restorative Dent 1988;8(4):9- 32

24. Cortellini P, Pini- Prato G, Baldi C, Clauser C. Guided tissue regeneration with defferent materials. Int J Periodontics Restorative Dent 1990;10:137- 151

25. Proestakis G, Bratthall G, S?erholm, Kullendorff B, Gr?dahl K, Rohlin M, A ttstr? R. Guided tissue regeneration in treatment of infrabony defects in maxillary premolars. J Clin Periodontol 1992;19:766- 773

26. Kersten BG, Chamberlain ADH, Khorsandi S, Wikesj_UME, Selvig KA, Nilveus RE. Healing of the intrabony periodontal lesion following root conditioning with citric acid and wound clo- 
sure including an expanded PT FE membrane. J Periodontol 1992;63:876- 882

27. Genco RJ. A ntibiotics in treatment of human periodontal diseases. J Periodontol 1981;52:545- 558

28. Baker PJ, Evans RT, Coburn RA,
Genco RJ. T etracy cline and its derivatives strongly bind to and are released from the tooth surface in active form. J Periodontol 1983;54:580- 585

29. Walker CB, Gordon JM, Socransky S. A ntibiotic susceptibility testing of 
subgingival plaque samples. J Clin Periodontol 1983;10:422- 432

30. Buorvatn K, Skaug N, Selvig K. Inhibition of bacterial growth by tetracy clineimpregnated enamel and dentin. Scand $J$ dent Res 1984;92:508- 516

31. Walker CB, Pappas JD, T y ler KZ, Cohen S, Gordon JM. A pproaches to chemotherapy. III. A ntibiotic susceptibilities of periodontal bacteria. " in vitro" susceptibilities to eight antimicrobial agents. J Periodontol 1985;56:67- 74

32. Socransky SS, Haffajee AD. Effect of therapy on periodontal infections J Periodontol 1993;64:754- 759

33. Ingman $\mathrm{T}$, Sorsa $\mathrm{T}$, Suomalainen $\mathrm{K}$, et al. $\mathrm{T}$ etracy cline inhibition and the cellular source of collagenase in gingival crevicular fluid in different periodontal diseases. A review article. J Periodontol 1993;64:82- 88

34. Greenstein G. Clinical significance of bacterial resistance to tetracy clines in the treatment of periodontal diseases. J Periodontol 1995;66:925- 932

35. T onetti M, Cugini MA, Goodson JM. Zero order delivery with periodontal placement of tetracy cline- loaded ethy lene viny I acetate fibers. J Periodont Res 1990:243- 249

36. Gordon JM, Walker CB, Murphy JC, Goodson JM, Socransky SS. Concentration of tetracy cline in human gingival fluid after single doses. J Clin Periodontol 1981;8:117- 121

37. Rifkin BR, Vernilo AT, Golub LM. Blocking periodontal disease progression by inhibiting tissue- destructive enzy mes: A potential therapeutic role for tetracyclines and their chemically- modified analog. J Periodontol 1993;64:819- 827

38. Golub LM, Mcnamara T F, D'A ngelo G, Greenwald RA, Ramamurthy NS. A nonantibacterial chemically modified tetracy cline inhibits mammalian collagenase activity. J Dent Res 1987;66:1310- 1314

39. Christersson LA, Nordery d OM, Puchalsky CS. T opical application of tetracy cline$\mathrm{HCl}$ in human periodontitis. J Clin Periodontol 1993;20:88- 95

40. Gomes BC, Golub LM, Ramamurthy N. T etracy clines inhibit parathy roid hormoneinduced bone resorption in organ culture. Experiencia 1984;40:1273- 1275

41. Sasaki T, Ramamurthy NS, Golub LM. T etracy cline administration increases collagen synthesis in osteoblasts of diabetic rats: a quantitative autoradiographic study. Calcif T issue Int 1992;50:411- 419

42. Terranova VP, Pranzetti LC, Hic S, et al. A biochemical approach to periodontal regeneration: T etracy cline treatment of dentin promotes fibroblast adhesion and growth. J periodont Res 1986;21:330- 337

43. Park YJ, Nam KH, Ha SJ, Pai CM, Chung CP, Lee SJ. Porous poly ( L- lactide) membranes for guided tissue regeneration and controlled drug delivery: membrane fabrication and characterization. J Control Release 1997;43:151- 160

44. Donath K, Breuner GA. A method for the study of undecalcified bones and teeth with attached soft tissues. J Oral Pathol 1982;11:318- 326

45. Loe H, Silness J. Periodontal disease in pregnancy. I. Prevalence and severity. Acta 
Odontol Scand 1963;21:533- 551

46. Silness J, Loe H. Periodontal disease in pregnancy. II. Correlation between oral hygiene and periodontal condition. Acta Odontol Scand 1964;22:121- 135

47. Bennett JV, Brodie JC, Benner EJ, Kirby WMM. Simplified, accurate method for antibiotic assay of clinical specimens. Applied Microbiology 1966;14:170- 177

48. Ciancio SG, Mather ML, McMullen $J A$. A $n$ evaluation of minocycline in patients with periodontal disease. J Periodontol 1980;51:530- 534

49. Christersson LA, Norderyd OM, Puchalsky CS. Topical application of tetracy cline- $\mathrm{HCl}$ in human periodontitis. J Clin Periodontol 1993;20:88- 95

50. Chung CP, Kim DK, Park YJ, Nam $\mathrm{KH}$, Lee SJ. Biologic effects of biodegradable membranes for guided bone regeneration. J Periodont Res 1997;32:172- 175

51. Kim WK, Choi SM, Chung CP, Han $\mathrm{SB}, \mathrm{K}$ won $\mathrm{YH}$, Lee SJ. Cellular activity and guided bone regenerative effect of drug- loaded biodegradable membranes. KAP 1997;27:129- 150

52. Markman C, Fracalanzza SEL, Novaes Jr. A B, Novaes A B. Slow release of tetracy cline hy drochloride from a cellulose membrane used in guided tissue regeneration J Periodontol 1995;66:978- 983

53. Mombelli A, Lang NP, Nyman S. Isolation of periodontal species after guided tissue regeneration. J Periodontol 1993;64:1171- 1175
54. Machtei EE, Cho MI, Dunford R, Norderyd J, Zambon JJ, Genco RJ. Clinical. microbiological, and histological factors which influence the success of regenerative periodontal therapy. J Periodontol 1994;65:154- 161

55. Pitaru S, T al H, Soldinger M, Noff M. Collagen membranes prevent apical migration of epithelium and support new connective tissue attachment during periodontal wound healing in dog. J Periodont Res 1989;24:247- 253

56. Demolon IA, Persson GR, A mmons WF, Johnson RH. Effects of antibiotic treatment on clinical conditions with guided tissue regeneration: One- year results. J Periodontol 1994;65:713- 717

57. Sander L, Frandsen EVG, A rnbjerg $D$, Warrer K, Karring T. Effect of local metronidazole application on periodontal healing following guided tissue regeneration. Clinical Findings. J Periodontol 1994;65:914- 920

58. Rapley JW, Cobb CM, Killoy W J, Williams DR. Serum level of tetracy cline during treatment with tetracy cline- containing fibers. J Periodontol 1992;63:817- 820 
- 국문초록-

\section{실험적으로 치주염을 유발한 비 글견에서}

테트라싸이클린 함유 생분해성 차폐막의 항염효과

전형식1, 설양조 ${ }^{1}$, 박윤정 2 , 이용무 ${ }^{1}$, 구 영1, 류 인철 ${ }^{1}$, 이승진 ${ }^{2}$, 한수부 ${ }^{1}$ 최상묵 ${ }^{1}$, 권수경 3 , 정 종평1

${ }^{1}$ 서울대학교 치과대학 치주과학교실, 20 이화여 자대학교 약학대학, ${ }^{3}$ 을지의과대학교 치과학교 실

조직유도재생술 과정에 사용된 차폐막의 술 후 오염 혹은 시술부위의 감염으로 조직재생유 도가 제대로 이루어지지 않는 경우가 많이 있 다. 테트라싸이클린은 넓은 범위의 치주 원인 균에 효과적이고, 중성구 교원분해효소를 억제 함으로써 결합조직파괴를 억제하기 때문에 전 신적 혹은 국소적으로 치주질환 치료에 널리 이용되어져왔다. 이번 연구의 목적은 비글견에 실험적으로 치주염을 유발시킨 후 테트라싸이 클린 함유 차폐막을 이용하여 조직유도재생술 을 하고서 테트라싸이클린의 유리반응을 관찰 하는 것과 테트라싸이클린에 의한 항염, 항균효 과를 알아보는 것이다. 실험 2-3개월 전에 비 글견의 구강에서 치조골 결손부를 형성하여 치 주염을 유발시켰다. 결손부 형성 2-3개월 후 실험군으로 테트라싸이클린 함유 차폐막으로 조직유도재생술을 하였고, 대조군으로 테트라 싸이클린이 함유되지 않은 차폐막으로 조직유 도재생술을 하였고, 음성대조군으로 치은판막 술만을 하였다. 시술 전과 시술 후 $1,2,4$ 주 간 격으로 치은지수, 치태지수, 치은열구액의 양
및 혐기성 세균과 호기성 세균의 군락수를 측 정하였다. 술 후, $1,3,5,7$, 및 14일 간격으로 유리된 테트라싸이클린의 농도를 측정하였다. 테트라싸이클린 함유 차폐막은 임상적 치은지 수는 술 후 2, 4주째, 치태지수는 1, 2, 4주째 유의하게 감소하였다. $(p<0.05) 1$ 주에서 혐기 성 및 호기성 세균집락수는 테트라싸이클린 함 유 차폐막을 사용한 군이 약물이 함유되지 않 은 차폐막보다 유의성있게 적었다. $(p<0.001)$ 테트라싸이클린 함유 차폐막은 처음 1 일은 높 은 농도로 유리되었고 그 후 1주일 동안 일정하 게 MIC 이상으로 유리되었다. 하지만 14일째 는 유리가 관찰되지 않았다. 본 연구 결과, 테트 라싸이클린 함유 생분해성 차폐막은 1 주이상 약제가 MIC 이상 유리되었고, 유리된 테트라싸 이클린에 의한 항염, 항균작용이 있어 치주조직 재생유도술시에 초기 치유가 잘 진행되도록 하 는 효과가있을 것이다. 